\title{
困による推論を考慮した建築の空間構成の記述方法 および類似事例検索への適用 \\ A METHOD OF DESCRIPTION THE COMPOSITION OF ARCHITECTURAL SPACE BY DIAGRAMMATIC REASONING AND ITS APPLICATION
}

\author{
曹。波*, 林田和 人**, 渡辺仁史*** \\ Bo CAO, Kazuto HA YASHIDA and Hitoshi WATANABE
}

\begin{abstract}
In this paper, in order to understand and analysis the differentiate and similarity features of composition of architectural space, a method of describe the composition of architectural space by using Diagrammatic Reasoning and a distinction methods of the similarity of composition of architectural space are proposed. As a application, the proposed methods are introduced to our recently developed supporting system which is based on Case-Based Reasoning for design thinking processing to enhance retrieve of similarity of the space status for the design case.
\end{abstract}

Keywords: Composition of Architectural Space, Room Planning, Diagrammatic Reasoning, Case-Based Reasoning, Similarity

建策空間構成, 室配置, 図による推論, 事例ベース推論, 類似性

\section{1. はじめに}

建築の空間構成を中心とする建築設計では、図を主要な思考手法 とすることは最も基本的なことである。そのため、設計思考支援の ための知的CADシステムを構筑するには、製図作業という図による 問題解決ではなく、設計過程における図による空間思考を支援する 問題解決こそが重要で不可欠である。

人工知能および情報処理の研究分野では、今まで知識表現の手段 として、主に言語的表現を用いてきたが、空間が問題対象である場 合には、人間の思考過程を純粋に言語的表現だけを使った論理的な 過程としてモデル化するのでは不十分であり、問題解決能力にも限 界があることが指摘されてきた。しかし近年、人工知能の分野で図 を積極的に活用し、図形の表現方法および図形を対象とする推論を 行う問題解決方法に関する研究という「図による推論(Diagrammatic Reasoning)」への関心が高まっている 間推論、幾何推論、類推、視覚的プログラミング、画像理解などの 研究と密接な関わりを持ちながら進められている。それらの研究は 基礎的な研究だけでなく、各々の分野で応用面の研究も進められて いる。

一方、建築設計の分野でも、人工知能と情報処理の技術手法を用 いた図の形態研究について幾つかがあげられる。太田は建築計画的
に意味のある空間の単位 Sとその相互関係 Lを機能図として、生活 機能と建築空間の相互関係の表現を述べた(51。近年服部は住宅プラン のn-LDKのように、記号化された建築の空間構成を記述する形式言 語（生成文法）を提案し、その図形記述言語の可能性を述べた(10)。青 木は建築空間分析のためのスキーマグラマーによる一連の研究にお いて、建築設計における図式性の概念の重要性を議論して、文法規 則やその導出過程そのものが建築形態の特徴や意味を反映したもの となるという視点で、スキーマグラマーという概念とこれに基づく 空間分析方法を提案しだ]。さらに、SALという建築平面記述言語で 平面構成を機械的に記号列で表記する方法を提案し、その文法を満 足する平面かどうかを判定するパージング方法を述べ、与えられる 平面を規定している文法を構成する方法を示した181。

本研究では、建築空間の差異と類似性という特徵を理解し把握す るため、従来の形式文法による㞬間構成の記述方法とは異なり、建 築の空間記述の簡素さおよびそのシステム化の実現的な容易さの面 を考え、図による推論という問題解決方法を用いて、新たな建築の 空間構成の記述方法およびその空間の類似性の判別方法を提案す る。さらに、これらの方法を、著者らが近年研究を行っている事例 ベース推論による設計支援システムに導入し、設計事例の空間の類 似性に関する類似検索機能を拡張することについても述べる。

\footnotetext{
* 早稲田大学理工学総合研究センター 客貝研究員・工博

Visiting Research Fellow; Advanced Research Institute for Science \& Engineering, Waseda Univ., Dr. Eng.

** 早稲田大学理工学総合研究センター 客貣講師・工博

*** 早稲田大学理工学部建築学科 教授・工博

Visiting Research Lecturer, Advanced Research Institute for Science \& Engineering, Waseda Univ., Dr. Eng.

Prof., Department of Architecture, School of Science \& Engineering, Waseda Univ., Dr. Eng.
} 


\section{2. 問題対象の定義}

建築の空間構成は寸法という単純な幾何学的関係だけではなく、 基本空間の方位、用途、機能、行動などの意味という関係をもって いる。建築設計の初期段階においては、建築の室の機能と位置など の相互関係を思考することが重要で、室の具体的な寸法を決定する 前の段階であると考えられる。つまり、室の寸法が少し違っていて も、室の機能と位置関係が同じなら、思考過程にあまり影響しない ものと考えられる。図1に示すように、Aは初期設計時の室単位空間 の位置関係を示している。Bは、線で結ばれた二室の間に直接通路が あり、初期設計時の室単位空間の間に相互連結関係があることを示 している。CはAとBに基づく最終設計案で、具体的な寸法を付けた 図面である。建築設計についての上記の考え方と図式化（図 1）は 参考文献191101に基づいている。

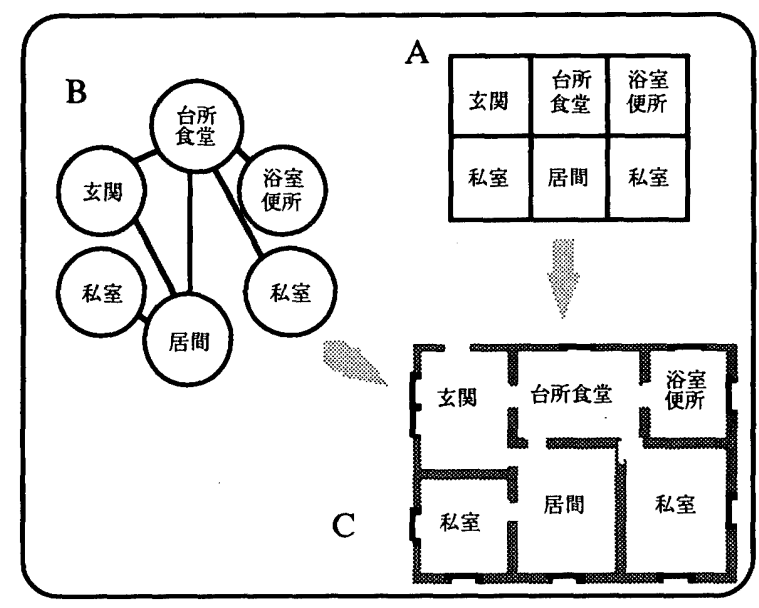

図1. 室の機能と位置関係図

本論文では、このような室配置という空間構成を問題対象とする 場合に、空間の寸法を具体的に表現せず、室空間の機能や連結関係 などの意味を重点とする記述方法及び評価方法を考える。

ここで問題を記述するため、次の概念を説明する。

建築空間とは常識的な意味で、建物の外部形態とその内部空間の 単位、種類およびその相互関係からなるものである。建築の圶間構 成を理解する視点も、その規模、距離関係、隣接、用途、行動上の 意味など多いが、その中で本論文では、建物内部の室の用途、室の 隣接関係、および通路の連結関係に着目する。これらの概念は次の ように定義する。

隣接関係とは、室と室が空間的に接しているという空間の単純な 位置関係である。

連結関係とは、室と室の間がドアなどにより、直接通行の可能性 を持つ関係である。

また、この隣接および連結関係を総称する場合には、連接関係と 示す。

以上の背景をもとにして、本諭文では、建築空間の機能、連接関 係に着目し、建築の空間構成についての空間記述方法、およびその 空間に関する類似性の判別方法を示す。さらに、設計事例の空間の 差異を求めることによって、それらの方法を、設計事例の類似検索 を行うことに適用する。

\section{3. 空間構成の記述方法}

前章で議論した建築の空間構成という問題対象の記述を簡略化し て表現するために、次の条件を前提にして空間構成の記述方法を考 える。

1) 住宅の室配置を問題対象とする。

2) 常識的な意味の室を単位空間として、その形状は矩形として考 える。

3) 空間の具体的寸法は表現しない。

4) 室の機能、室の隣接と連結関係という空間関係を評価要素とす る。

以上を前提として、次に示すような記述方法で空間構成を定義す る。

$$
S=(\Sigma, V, A, P)
$$

ただし、

$\Sigma:$ 建築の空間構成における常識的な意味の室という具体 的な単位空間の集合である。

$\mathrm{V}$ : 室の類型の集合である。単位空間の室の類型は次のよ うに定義する。ある室空間は必ず一つの室類型に属す る。

$\mathrm{B} ：$ 私室

$\mathrm{L}$ : 居間

$\mathrm{W}$ : 洗面、浴室、便所

D K : 台所、食堂

$\mathrm{H}:$ 玄関ホール

$\mathrm{A}$ ：室空間の隣接と連結関係を記述する関係関数の集合で ある。これらの関係関数は次のように定義する。

Above $(x, y): x \in \Sigma 、 y \in \Sigma$ 且つ

室xが室yの上にあるという二つの室空間の 隣接関係。

Left( $x, y): x \in \Sigma 、 y \in \Sigma$ 且つ

室xが室yの左にあるという二つの室空間の

隣接関係。

$\operatorname{Move}(x, y): x \in \Sigma 、 y \in \Sigma$ 且つ

室 $\mathrm{x}$ と室yの間に直接通行の可能性を持った 連結関係。ここで、この関数の二つのパラ メータの順番には関係がない。つまり、 $\operatorname{Move}(\mathrm{x}, \mathrm{y})=\operatorname{Move}(\mathrm{y}, \mathrm{x})$

$\mathrm{P} ： \mathrm{~A} て ゙$ 定義した関係関数により、指定した条件をすべて 満たす関係関数の集合である。

上述の空間記述方法を解説するため、図2の室配置を例として具体 的に説明する。図2の( )外の符号を室名とし、（）内の符号を室の類 型とする。太い記号「一」は、二室の間に通路があることを示す。 図2の空間構成をS1とし、その構成要素は $\Sigma 1, \mathrm{~V} 1, \mathrm{~A}$ *,P 1からな る。ここでA*は、前述した空間構成SにあるA要素と同じである。図 2 はx1,x2,x3,x4,x5,x6という 6 つの室空間によって構成される室配 置である。各室の類型については、x1室は玄関ホール、x2室は台所 と食堂、x3室は洗面と浴室と便所、x5室は居間、 $x 4$ と $x 6$ 室は私室で ある。各室の間の隣接関係と連結関係は、Above $(x, y)$ 関数が $3 つ 、$ 


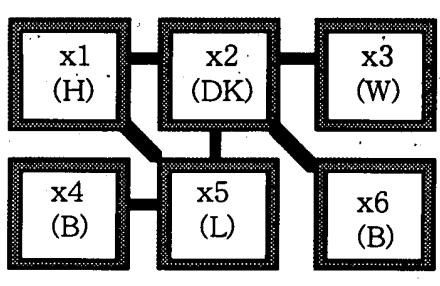

図2. 室配置の例(S1)

Left $(\mathrm{x}, \mathrm{y})$ 関数が 4 つ、Move $(\mathrm{x}, \mathrm{y})$ が 6 つからなる。この空間構成の記 述 S 1を図3に示す。

$\mathrm{S} 1:=\{\Sigma 1, V 1, A *, P 1\}$

$\Sigma 1:\{x 1, x 2, x 3, x 4, x 5, x 6\}$

$\mathrm{V} 1: \mathrm{B}=\{\mathrm{x} 4, \mathrm{x} 6\}$

$\mathrm{L}=\{\mathrm{x} 5\}$

$W=\{x 3\}$

$\mathrm{D} \mathrm{K}=\{\mathrm{x} 2\}$

P $1: 1$

$\mathrm{H}=\{\mathbf{x} 1\}$

Above (x1,x4) Above (x2,x5) Above( $x 3, x 6)$

Left(x1,x2) Left( $x 2, x 3)$ Left $(x 4, x 5) \operatorname{Left}(x 5, x 6)$

$\operatorname{Move}(x 1, x 2) \quad \operatorname{Move}(x 1, x 5) \quad \operatorname{Move}(x 2, x 3)$.

図3. 空間構成 $S 1$ 記述

\section{4. 空間の類似性の判別}

設計者にとって、空間の差異と類似性を把握することは建築空間 を設計していく上で重要である。しかし：異なる建築空間の差異と 類似性に対して、その評価尺度は極めて曖昧で、体系化された方法 がないのが現状である。本論文では、建築の室という空間の差異を 判別するため、前に述べた室空間の類型と、それらの隣接関係と連 結関係に着目した評価尺度を考える。

ここで解説のために、もう一つの空間構成" 22 を例として、次の図4 に示す。

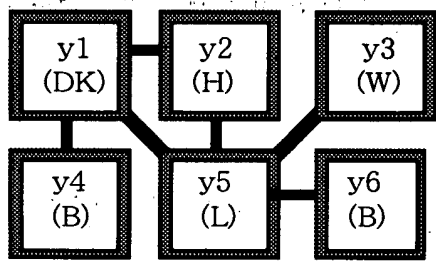

図4. 室配置の例(S2)

図4に対応する㞬間構成S2を次の図5に示すが、その構成要素は $2, \mathrm{~V} 2, \mathrm{~A}^{*}, \mathrm{P} 2$ からなる。ここでA*は、前述した空間構成SにあるA要 素と同じである。図4の室配置はy1,y2,y3,y4,y5,y6から構成され る。各室の類型については、y1室は台所と食堂、y2室は玄関ホー ル、y3室は洗面と浴室と便所、y5室は居間、y4と $\mathrm{y} 6$ 室は私室であ る。各室の間の隣接関係と連結関係は、Above $(x, y)$ 関数が 3 つ、

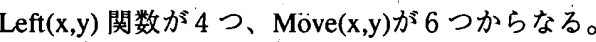

$\mathrm{S} 2=\{\Sigma 2 、 \mathrm{~V} .2 、 \mathrm{~A} * \mathrm{P}, 2\}$

$\Sigma 2:\{y 1, y 2, y 3, y 4, y 5, y 6\}$

$\mathrm{V} 2: B=\{\mathrm{y} 4, \mathrm{y} 6\}$

$\mathrm{L}=\{\mathrm{y} 5\}$

$\mathrm{W}=\{\mathrm{y} 3\}$

$\mathrm{D} \mathrm{K}=\{\mathrm{y} 1\}$

$\mathrm{H}=\{\mathrm{y} 2\}$

P 2: \{

Above(y1,y4) Above(y2,y5) Above(y3,y6)

$\operatorname{Left}(\mathrm{y} 1, y 2) \operatorname{Left}(\mathrm{y} 2, \mathrm{y} 3) \operatorname{Left}(\mathrm{y} 4, \mathrm{y} 5) \quad \operatorname{Left}(\mathrm{y} 5, \mathrm{y} 6)$

Move(y1,y2) Move(y1,y4) Move(y1,y5)

Move(y2,y5) Move(y3,y5) Move(y5,y6)

図5. 空間構成 $S 2$ の記述

\section{1 室の類型の評価}

評価方法として、前に述べた記述方法を用いて記述されている二 つの建築空間構成のS1とS2における室という単位空間の構成集合 （ $\Sigma 1 、 \Sigma 2 ）$ の間のすべての室について、同じ類型の室を照合す る。照合した結果により、次の計算式を用いて室の類型の類似度を 求める。

$$
\text { 室の類型の類似度 }=1-\frac{\sum_{\mathrm{k}=1}^{5}\left[\psi\left(\mathrm{S}_{\mathrm{i}}, \mathrm{U}_{\mathrm{k}}\right)-\psi\left(\mathrm{S}_{\mathrm{j}}, \mathrm{U}_{\mathrm{k}}\right)\right]^{2}}{\sum_{\mathrm{k}=1}^{5}\left[\psi\left(\mathrm{S}_{\mathrm{i}}, \mathrm{U}_{\mathrm{k}}\right)+\psi\left(\mathrm{S}_{\mathrm{j}}, \mathrm{U}_{\mathrm{k}}\right){ }^{2}\right.}=1-\frac{\gamma}{\zeta}
$$

$<$ 式1>

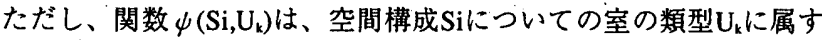
る室の数である。ここで、SiとSj は異なる二つの空間構成であり、 $\mathrm{U}_{\mathrm{k}}$ は前に定義した室類型 $\mathrm{V}=\{\mathrm{B} ; \mathrm{L} ; \mathrm{W}, \mathrm{DK}, \mathrm{H}\}$ の要素である。この式によ り、同じ類型の室が多い場合には式の値が1に近くなり、同じ類型の 室が少ない場合には 0 に近くなる。つまり、室の類型の類似度は 0 から 1 までの值となる。

例とする空間構成 S 1 と S 2 の場合に、室類型の類似度計算は次の ようになる。

$\gamma=(\psi(\mathrm{S} 1, \mathrm{~B})-\psi(\mathrm{S} 2, \mathrm{~B}))^{2}+(\psi(\mathrm{S} 1, \mathrm{~L})-\dot{\psi}(\mathrm{S} 2, \mathrm{~L}))^{2}$

$+(\psi(\mathrm{S} 1, \mathrm{DK})-\psi(\mathrm{S} 2, \mathrm{DK}))^{2}+(\psi(\mathrm{S} 1, \mathrm{~W})-\psi(\mathrm{S} 2, \mathrm{~W}))^{2}$

$+(\psi(\mathrm{S} 1, \mathrm{H})-\psi(\mathrm{S} 2, \mathrm{H}))^{2}$

$=(2-2)^{2}+(1-1)^{2}+(1-1)^{2}+(1-1)^{2}+(1-1)^{2}$

$=0$

$$
\begin{aligned}
\zeta & =(\psi(\mathrm{S} 1, \mathrm{~B})+\psi(\mathrm{S} 2, \mathrm{~B}))^{2}+(\psi(\mathrm{S} 1, \mathrm{~L})+\psi(\mathrm{S} 2, \mathrm{~L}))^{2} \\
& +(\psi(\mathrm{S} 1, \mathrm{DK})+\psi(\mathrm{S} 2, \mathrm{DK}))^{2}+(\psi(\mathrm{S} 1, \mathrm{~W})+\psi(\mathrm{S} 2, \mathrm{~W}))^{2} \\
& +(\psi(\mathrm{S} 1, \mathrm{H})+\psi(\mathrm{S} 2, \mathrm{H}))^{2} \\
& =(2+2)^{2}+(1+1)^{2}+(1+1)^{2}+(1+1)^{2}+(1+1)^{2} \\
& =32
\end{aligned}
$$

室の類型の類似度 $=1-\gamma / \zeta=1-0 / 32=1$

\section{2 室の連接関係の評価}

室の連接関係は、位置の隣接関係と通路の連結関係を含む。その 
評価方法として、前に述べた空間構成の記述方法を用いて記述され ている二つの建築空間構成の関係関数集合の間で、全ての構成関数 の照合を行う。その照合過程では、照合されるそれぞれの関数を構 成する室の類型が同じ類型かどうかを比較する。

照合規則を、次のように隣接照合規則と連結照合規則に分けてそ れぞれを示す。任意の空間構成 S 1 と S2の場合には、次のように定 義される。

·瞵接照合規則 :

もし、S1の関数 $A \operatorname{bove}(x, y) \quad x, y \in \Sigma 1$ 且つ $x \subset v 1, y \subset v 2$ S2の関数Above $(a, b) \quad a, b \in \Sigma 2$ 且つ $a \subset v 3, b \subset v 4$ 且つ $v 1=v 3, v 2=v 4, v 1, v 2 \in V 1 v 3, v 4 \in V 2$

則 : 関数Above $(x, y)$ と関数Above $(a, b)$ は照合する。

ここで、 $\mathrm{x} \subset \mathrm{v}$ は $\mathrm{x}$ 室がv類型であることを示す。次の解説でも同じ意 味である。

もし、S1の関数 Left $(\mathrm{x}, \mathrm{y}) \quad \mathrm{x}, \mathrm{y} \in \Sigma 1$ 且つ $\mathrm{x} \subset \mathrm{v} 1, \mathrm{y} \subset \mathrm{v} 2$ S2の関数Left(a,b) $a, b \in \Sigma 2$ 且つ $a \subset v 3, b \subset v 4$ 且つ $v 1=v 3, v 2=v 4, v 1, v 2 \in V 1 v 3, v 4 \in V 2$

則：関数Left $(x, y)$ と関数Left $(a, b)$ は照合する。

室の隣接の類似度を、これらの照合規則によって、次の計算式を 用いて求める。

室の隣接の類似度 $=2 \mathrm{M}_{\mathrm{L}}(\mathrm{S} 1, \mathrm{~S} 2) /\left(\mathrm{N}_{\mathrm{L}}(\mathrm{S} 1)+\mathrm{N}_{\mathrm{L}}(\mathrm{S} 2)\right)<$ 式2> ただし、

$\mathrm{N}_{\mathrm{L}}(\mathrm{S} \mathrm{i})$ は空間構成 $\mathrm{Si}$ の関数集合 $\mathrm{Pi}$ 含まれる隣接関係 関数の数

$\mathrm{M}_{\mathrm{L}}(\mathrm{S} 1, \mathrm{~S} 2)$ はS1の関数集合 $\mathrm{P} 1$ とS2の関数集合 $\mathrm{P} 2$ に含ま れる隣接関係関数の間の照合数

この式により、隣接関係関数の照合数が多い場合には式の值が1に 近くなり、照合数が少ない場合には $0 に$ 近くなる。つまり、室の隣 接の類似度は 0 から 1 までの值となる。

・連結照合規則：

もし、S 1の関数 $\operatorname{Move}(\mathrm{x}, \mathrm{y}) \quad \mathrm{x}, \mathrm{y} \in \Sigma 1$ 且つ $\mathrm{x} \subset \mathrm{v} 1, \mathrm{y} \subset \mathrm{v} 2$ $\mathrm{S} 2$ の関数Move(a,b) $\mathrm{a}, \mathrm{b} \in \Sigma 2$ 且つ $\mathrm{a} \subset \mathrm{v} 3, \mathrm{~b} \subset \mathrm{v} 4$

且つ $\mathrm{v} 1=\mathrm{v} 3, \mathrm{v} 2=\mathrm{v} 4, v 1, \mathrm{v} 2 \in \mathrm{V} 1 \mathrm{v} 3, \mathrm{v} 4 \in \mathrm{V} 2$

則 : 関数 $\operatorname{Move}(\mathrm{x}, \mathrm{y})$ と関数Move $(\mathrm{a}, \mathrm{b})$ は照合する。

室の連結の類似度を、これらの照合規則によって、次の計算式を用 いて求める。 室の連結の類似度 $=2 \mathrm{M}_{\mathrm{M}}(\mathrm{S} 1, \mathrm{~S} 2) /\left(\mathrm{N}_{\mathrm{M}}(\mathrm{S} 1)+\mathrm{N}_{\mathrm{M}}(\mathrm{S} 2)\right)$ <式3> ただし、

$N_{M}(S i)$ は空間構成 $S i$ 関数集合 $P i に$ 含まれる連結関係 関数の数

$\mathrm{M}_{\mathrm{M}}(\mathrm{S} 1, \mathrm{~S} 2)$ はS1の関数集合P 1 とS2の関数集合 P 2に含ま

れる連結関係関数の間の照合数

この式により、連結関係関数の照合数が多い場合には式の値が1に 近くなり、照合数が少ない場合には 0 に近くなる。つまり、室の連 結の類似度は 0 から 1 までの值となる。

以上の照合規則および計算式を解説するため、前に定義した空間 楎成のS 1とS2を例として説明する。図6には隣接照合過程を示す。
図 6 の両側にある関数リストは空間 S 1 と空間 S2を構成する隣接関 係の関係関数集合である。この二つの関数集合の間において、点線 で䋈いでいる関数が照合することを示す。線で轱がっていない関数 は、照合できないことを示す。照合の結果により室空間の隣接の類 似度は次の結果となる。

$$
\begin{aligned}
& \mathrm{M}_{\mathrm{L}}(\mathrm{S} 1, \mathrm{~S} 2)=3 \\
& \mathrm{~N}_{\mathrm{L}}(\mathrm{S} 1)=7 \\
& \mathrm{~N}_{\mathrm{L}}(\mathrm{S} 2)=7
\end{aligned}
$$

式 2 によって、室の隣接の類似度 $=2 * 3 /(7+7)=3 \pi$

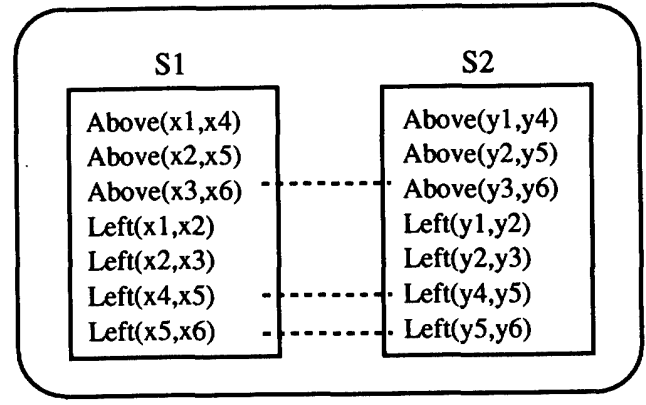

図6. 隣接照合過程

図 7 には連結照合の過程を示す。図6の隣接照合過程のように、 図 7 の再側にある関数リストは空間 S 1 と空間 S 2 を粠成する連結関 係の関係関数集合である。この二つの関数集合の間において、点線 で紫いでいる関数が照合することを示しており、線で䌘がっていな い関数は照合できないことを示す。

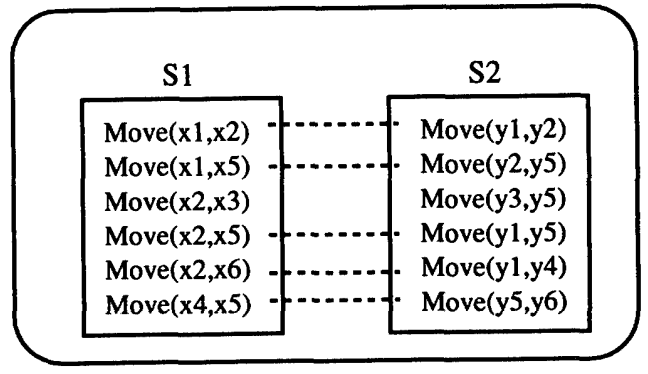

図7. 連結照合過程

照合の結果により室空間の連結類似度は次の結果となる。

$$
\begin{aligned}
& M_{M}(S 1, S 2)=5 \\
& N_{M}(S 1)=6 \\
& N_{M}(S 2)=6
\end{aligned}
$$

式 3 によって、室の連結の類似度 $=2 * 5 /(6+6)=5 / 6$

\section{5. 類似事例の検索への応用}

著者らは近年、事例ベース推論による設計支援システムに関する 研究を行なっているが清、建築設計は模做から始まって新たな建築 秌間を創造する過程という視点から、本システムでは設計案に対し て類似している既存設計事例から、設計手法および設計解を取得す るという問題解決方法を考えている。

前報の文[11]中に述べた事例ベース推論システムの問題解決方法 は図 8 のように、設計条件が与えられた時に、その設計条件の特徵 に従って、事例ベースから設計問題にもっとも類似している事例を 取り出すという方法である。ここでは、利用者は類似事例の設計解 
と設計手法などを用いて新しいイメージを発想するという設計支援 過程を想定している。その事例ベース推論過程において、設計の条 件を記述する属性特徴を照合対象と考えて類似事例を検索していた が、設計事例の図面に関する類似性については言及していない。

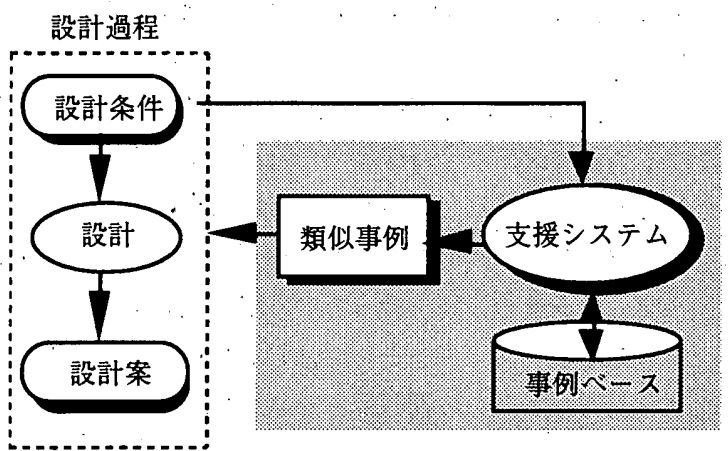

図8. 事例による設計支援システムの枠組み

そこで本論文では、前に述べた空間構成の記述方法およびその空 間の類似性の判別方法を事例ベース推論による設計支援システムに 導入し、設計案と既存の設計事例の間における建築空間の類似性を 求めることにようて事例の類似検索を行う。以下、システムの実行 過程を具体的に解説する。図9に示すのは、提案した方法により図に よる推論を考慮した類似事例の検索過程である。なお、図9と図10で は、設計案をS1、設計事例をS2として説明している。

1) 建等の空間構成の定義

まず、設計案に対して、利用者がシステムのインタフェースを通 して、画面で設定しながら、その空間構成を定義する（図9のA）。

具体的には、まずシステムが 9 または 16 個の単位空間のテンプ レートを提供する。次に利用者は、設計案の室の機能、隣接、連結 関係に従って、このテンプレートの単位空間を選択し、選択した単 位空間に対してシステム画面のメニューから室の類型を選び、また 単位空間の間の境界線をクリックすることによって、通路を設定す、 る。図10では、深い色の 6 つの単位空間が室に設定され、それぞれ の室の機能、通路関係が設定されている状態である。

2) 空間記述の生成

定義した空間構成に対して、シスデムが前述した空間記述方法を 用いて、システム画面の空間構成から内部記述形式に変換し、空間 の室に対してその室の類型集合、関係関数を生成する (図9のB)。 また、関係関数の生成の際に、空間構成の整合性に関する検証も行 う。例えば、玄関を空間の真中に配置した場合には、システムがそ の整合性を自動的に判断する。

3) 関係関数の照合

設計案と設計事例の関係関数集合に対して、システムの推論エン ジンが、前述した隣接照合規則と連結照合規則を用いて関係関数の 照合を行う（図 9 の）。

4) 類似度の計算

関係関数を照合した結果に基づいて、前述した空間の類似性の判 別方法を用いて、与えられた設計条件に従って作成した設計案の空 間形態と、事例ベースに保存されている事例の劦間形態との類似度 を求める（図9のD）。これは空間の類型類似度、隣接類似度、連結
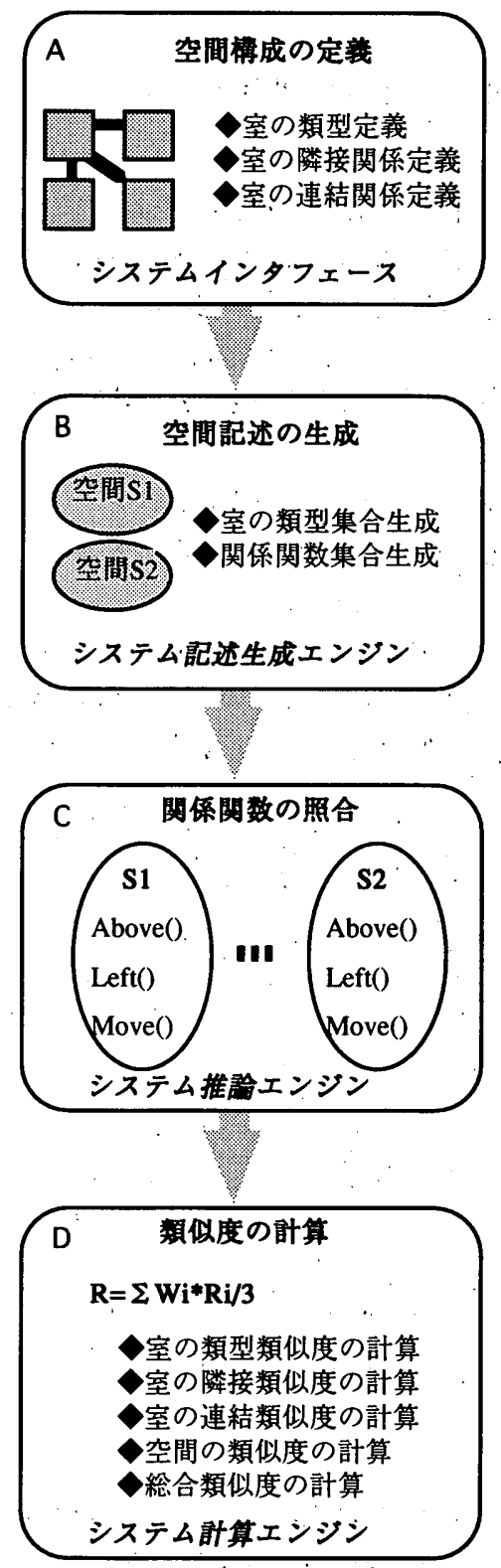

図9. 図による推論を考慮した類似事例の検索過程

類似度からなり、問題解決に役立つ程度を判断してそれぞれに重み づけをして、計算された類似度を合計する。つまり、次の式4に示す 類似度の計算方法を用いて、設計案と設計事例との空間の類似度を 求めるのである。

$$
\begin{aligned}
& \text { 空間の類似度 } \mathrm{R}=\sum_{\mathrm{i}=1}^{3} \mathrm{Wi}^{*} \mathrm{Ri} / 3 \\
& \mathrm{R} 1 \text { ：室の類型照合に関する類似度 } \\
& \mathrm{R} 2 \text { ：室の隣接照合に関する類似度 } \\
& \mathrm{R} 3 \text { ：室の連結照合に関する類似度 } \\
& \text { Wi : Riに対する特徴重み. }
\end{aligned}
$$

さらに、事例の類似度の計算については、文[11]中において、設 計案と設計事例の一般特徵に対して事例の類似度の計算方法を述べ たが、ここでは、設計事例の空間特徴を考慮した事例の類似度の計 算方法を次のように述べる。 
釉合類似度 $=\left[\left(\sum_{i=1}^{n} W_{i} * M i\right)+W * R\right] / \sum_{i=1}^{n} M i+1 \quad$ <式5>

ただし、Wiは設計案の一般特徵の第i特徵に対する重みであり、W は空間の類似度の重みである。Miは設計案と設計事例の第 $i$ 特徽に関 する照合度であり、設計案の特徵が事例の特徴と照合する場合には 1、照合しない場合には 0 と定義される。ここでnは設計案の一般特 徵の数である。Rは、式4により求められた設計案と設計事例の空間 の類似度である。

本システムでは、利用者が設計案の特徽について、問題解決に役 立つ程度を判断して重みづけをすることができる。そして、システ ムが設計案と設計事例とを照合する上で、それらの重みを用いて上 述の類似度の計算式で事例ベースにある各事例との類似度を計算 し、類似度が高い候補事例を選ぶ。つまり、利用者が設定した重み により、問題解決に役立つ類似事例が選ばれるのである。

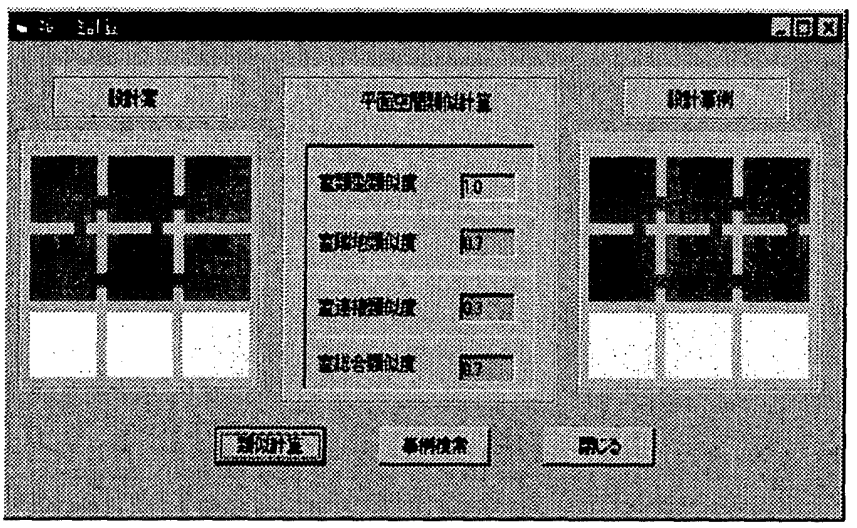

図10. システム画面

\section{6. まとめ}

本論文では、建築空間の差異と類似性という特徽を理解し把握す るため、室の配置を問題対象とする建箱空間構成の記述方法、およ び室空間の類型と連接関係を中心とする評価方法を述べた。さら に、これらの方法を、文[11]で開発を行っている事例ベース推論に よる設計支援システムに導入し、空間の類似性に関する類似検索機 能を拡張することについても述べた。これらの概念を実際のシステ ムに実装することにより、提案した方法の有用性を明らかにするこ とができた。

本論文では図による推論を考慮した建築の空間記述方法および空 間の評価方法を示すことが主要な目的であり、解説をわかりやすく するため、空間の記述方法に関してもっとも基本的なものを解説 し、空間構成の例についても単純な建築空間を例とした。しかし、 本論文で提案した空間記述方法は容易に拡張することができる枠組 みである。これらの点について、以下のように補充説明を行う。

室の類型については、私室、居間、（洗面、浴室、便所）、（台 所、食堂）の5つに分類しているが、本記述方法では、別の分類で も可能な仕組みとなっているため、様々な視点から分類すれば複雑 な空間構成が記述できる。例えば、浴室、便所を別の類型にするこ とも可能で、また、廊下や階段を一つの類型として扱うことも可能
である。

関係関数については、設計初期の建棐イメージを発想する段階に おいては、建築空間の機能、位置、移動関係が重要であり、また提 案方法を解説しやすくするという理由で、その関係を記述できるも っとも基本的な関係関数のAbove,Left,Moveを選んで提案方法を解説 した。しかし、関係関数を拡張すれば、襩雑な空間構成を記述する ことが可能である。

また、空間構成の記述方法の要素Pには、関係関数の論理的組合わ せが含まれるべきであるが、今回論文を解説しやすくするため、論 理的組合わせの内容に言及していない。空間構成の整合性について は、利用者が定義した空間構成を内部記述形式に変換する際に、シ ステムが空間の整合性の検証を行っているが、検証できない部分に ついては、空間記述レベルおよび推論過程での整合性の判断方法を 考える必要がある。これらの問題点を今後の課題として検討したい と考えている。

\section{参考文献}

[1]特集「図による推論」, 人工知能学会誌, Vol.9 No.2, 1994

[2]岩崎由美：図による推論と定性推論, 人工知能学会誌, Vol.9 No.2, pp.183-189, 1994

[3]中谷善雄 : 困による推論の研究の最新動向, 人工知能学会誌, Vol.9 No.2, pp.210-215, 1994

[4]開一夫、安西祐一郎 : 空間的関係の推論と学習, 人工知能学会誌, Vol.9 No.2, pp.205-209, 1994

[5]池邊陽（主査）：設計方法III, 日本建築学会建築計画委員会, 1974 [6]服部岑生：建築の空間構成を記述する形式言語（生成文法）の可 能性, 日本建築学会計画系論文集, No.446, pp.89-97, 1993 [7]青木義次, 大佛俊泰：スキーマグラマーによる空間分析の方法論 と都市プランへの応用ー建築空間分析のためのスキーマグラマーに 関する研究 その一、日本建築学会計画系論文集, No.446, pp.99109, 1993

[8]青木義次: 建築平面記述言語と空間構成解析方法, 日本建築学会 計画系論文集, No.494,pp.153-159, 1997

[9]黑沢和隆：住宅平面計面へのパターン分析手法の適用性に関する 研究, 日本建築学会計画系論文報告集, No.381, pp.90-99, 1987

[10]黑沢和隆：動線条件から平面構成パターンを導く図法を用いた 住宅平面型のパターン分析手法, 日本建築学会計画系論文報告集, No.392, pp.41-50, 1988

[11]曹波, 渡辺仁史：事例べース推論による設計初期段階における思 考過程の支援システムに関する研究，日本建築学会計画系論文集， No.496, pp.255-261, 1997

（1999年 6 月 8 日原稿受理，1999年12月 9 日採用決定） 